\title{
Citizens without Nations: A Response
}

\author{
MAARTEN PRAK \\ Department of History, Utrecht University \\ Drift 6, 35 I2 BS Utrecht, The Netherlands
}

E-mail:m.prak@uu.nl

\begin{abstract}
AвSTRACT: In Citizens without Nations, I argued that national histories have overlooked a large and significant range of citizenship practices that can be found in towns and cities across the pre-modern world. These practices related to local politics (elections, consultations), to economic activities (guilds), to social policies (poor relief), and to military defence (civic militias). This rejoinder addresses three issues raised by critics Jack Goldstone, Katherine Lynch, and R. Bin Wong in relation to my book on urban citizenship in Europe, Asia, and the Americas: ideas, including religion, nations, and economic growth. All three have a lot to do with the implications of global comparisons. Ideas and nations have taken distinct forms in the various world regions. Foregrounding them makes comparisons more difficult. Urban contexts, on the other hand, can be more easily compared. Economic development was introduced in the book as a benchmark to see if and how citizenship arrangements might have impacted prosperity. The economic numbers are, however, still fragile for the pre-industrial era. Therefore, they will have to be supplemented with qualitative studies, which are slowly but surely emerging also outside Europe.
\end{abstract}

Citizens without Nations was written with some of the great historical sociologists in mind, most notably Charles Tilly, whose work on rebellion, on state formation, and, indeed, on citizenship had a big impact on the text. ${ }^{\text {I }}$ One of the things I learned from Tilly is that it is fine to be wrong, provided it happens in an interesting way. At least I have managed to kindle the interest of three eminent scholars, some of whose work has been written in

I. Charles Tilly, Big Structures, Large Processes, Huge Comparisons (New York, I984); idem, Capital, Coercion, and European States, AD 990-1990 (Oxford, 1990); idem, European Revolutions, I492-1992 (Oxford, I993); idem, Contention and Democracy in Europe, I6502000 (Cambridge, 2004). On Tilly, see Marcel van der Linden, "Charles Tilly's Historical Sociology", International Review of Social History, 54 (2009), pp. 237-274. I think it is fair to say I share with all three reviewers this close connection with Tilly's person and work. 
the same spirit as my own book. I am honoured by the detailed, appreciative, but also critical reading of my work. I am also grateful, because this is precisely the sort of debate I had hoped to trigger with the publication of my book. Many of the critical points raised in these reviews are the result of choices I made. Therefore, before I respond to these specific points, I would like to state some of the objectives I had in mind when writing Citizens without Nations.

As Katherine Lynch explains in her contribution, this book emerged from two local studies I published, alas in Dutch, in my younger days, as well as from a survey of the Dutch Golden Age that explores the same topics, and finally from a book I wrote together with Jan Luiten van Zanden, also on Dutch history. ${ }^{2}$ In the first book, about Dutch urban elites, I was struck by how much these elite families identified themselves as citizens. The Dutch word for citizen is burger (burgher, in English) and it had - and still has a double meaning that these people were keen to exploit. Socially and culturally it means "middle class", or "bourgeois", in other words, nonaristocratic. Politically it means "citizen", and one of their claims was that they were "citizens like everyone else". My second book, a sort of prequel to Citizens without Nations, investigated civic organizations in the Dutch town of 's-Hertogenbosch, also known as Bois-le-Duc, before and after the French Revolution. In this study, I was struck by the popularity of these civic organizations, among elites, but also among ordinary people, and the huge efforts it took to eliminate them and make room for modern democracy. It convinced me that the Ancien Régime had its supporters not only among the aristocracy or the elites. I was also struck by how little was left of the agency of local people in the decades after the introduction of "democracy". In the two books on Dutch history it was argued that Dutch economic prosperity, which can be traced back to the Middle Ages, rested on a solid foundation of civic organizations with a major say in the workings of the state.

Initially, my idea was to upscale my work on the Dutch Republic to a European level, utilizing the many local studies of urban history that are only rarely integrated into broader narratives. ${ }^{3}$ However, at the time I first

2. Maarten Prak, Gezeten burgers. De elite in een Hollandse stad. Leiden $1700-1780$ [Hollandse Historische Reeks vol. 6] (Amsterdam/Dieren, I985); idem, Republikeinse veelheid, democratisch enkelvoud. Sociale verandering in het Revolutietijdvak: 's-Hertogenbosch I770-I820 (Nijmegen, 1999); idem, The Dutch Republic in the Seventeenth Century (Cambridge, 2005); idem and Jan Luiten van Zanden, Nederland en het poldermodel. Sociaal-economische geschiedenis van Nederland, 1000-2000 (Amsterdam, 2013) (an English translation is scheduled to appear with Princeton University Press in 2022).

3. Obvious exceptions are surveys like Christopher R. Friedrichs, The Early Modern City I4501750 (Harlow, I995), and Peter Clark, European Cities and Towns 400-2000 (Oxford, 2009), but what I had in mind was more like a qualitative version of Jan de Vries, European Urbanization, I 500-I 800 (London, I984). 
started to think about the contents of this new book, I was much involved in the Global Economic History Network (GEHN), led by Patrick O’Brien, where minds were strongly focused by Ken Pomeranz's book on the Great Divergence. ${ }^{4}$ It seemed to me that a discussion of citizenship outside Europe would help to cast new light on both the European experience and on world history in general and, possibly, the Great Divergence in particular. Therefore, I decided to include chapters on Asia and the Americas, knowing full well that I would be skating on thin ice as I am not an expert in either of the areas, and do not read Chinese or (Ottoman) Turkish. Instead, I read what I could understand in European languages, and asked colleagues with expertise in these various world regions to comment on my texts. Obviously, I am in no position to argue with Wong about Chinese history. I will, however, try to explain my choices in the face of his criticisms. In writing these two chapters I wanted to highlight a major distinction between my narratives of citizenship in Asia and the Americas: the citizenship practices I described in the Asian chapter originated in the towns and cities of these two Asian empires. I called them "original citizenship" to distinguish them from the imported citizenship of the Spanish and English colonies in the Americas. There was no deeper meaning intended and I should probably have made this more explicit in my book.

Finally, my purpose was to inject into the debate about institutions more "agency". Douglass North's approach to institutions focused on property rights. By implication, he was interested in the broader issues of the legal context of market transactions. It has become widely accepted that these were important. However, societies are clearly more than their economies, and economies require more in terms of institutions than laws and regulations. As a social historian, I wanted to think about where the people fit into this story, and how their behaviour might have made a difference to the quality of the societies they lived in. Unfortunately, that quality is not so easy to measure. I decided that the only way to do that, however incomplete or flawed, was to look at economic prosperity and use the best estimates we currently have for this purpose, and, where these are missing, to use data on urbanization as the best proxy. ${ }^{5}$ There will be more to say about this below.

From this point, I will turn to three major issues raised in the comments by Wong, Goldstone, and Lynch. These are ideas, including religion, nations, and economic growth - all related to citizenship, of course.

4. Kenneth Pomeranz, The Great Divergence: China, Europe, and the Making of the Modern World Economy (Princeton, NJ, 2000).

5. For a much broader approach, alas for the nineteenth and twentieth centuries only, see Jan Luiten van Zanden et al., How Was Life? Global Well-Being since I820 (Paris, 2014). 


\section{CITIZENSHIP AND IDEAS}

There is a vast literature that defines citizenship first and foremost as an idea. In its most abbreviated form, its history runs as follows. Citizenship was invented in the póleis of Ancient Greece, and subsequently adopted by the Romans to apply across their empire. After the collapse of the Roman Empire citizenship disappeared, to be reinvented as an idea during the Renaissance, but only reintroduced by the French Revolution. ${ }^{6}$ In this story, citizenship is an exclusively European phenomenon, and although it was invented in an urban context, that context was at the same time a state context, because Athens and the other póleis were city-states. Hence, we should apply citizenship only to European states. In my book, I wanted to move away from these restrictions in two ways. First, I wanted to apply the concept to local contexts, because I was convinced that much more was going on, politically and otherwise, in those local contexts than national histories tend to capture. Secondly, I wanted to avoid a definition that carried strong cultural implications. Wong's book China Transformed had alerted me to the dangers of intellectual strategies that hold out European concepts as the standard, and then condemn other civilizations for not having them. ${ }^{7}$ To avoid this trap, I applied a "practical" definition of citizenship in my book, which would allow an investigation of similar practices outside Europe. In the book, I do discuss ideas about citizenship and the civic community and point out that these indeed seemed to be absent in Asia. However, I refrain from emphasizing these differences too much, because I am not sure how I can measure their impact.

Goldstone equally sees the absence of ideas as a flaw in my argument. $\mathrm{He}$ claims that the significance of European citizenship was perhaps not in the idea of citizenship itself, but in its insistence on "freedom" as a necessary ingredient of civic life. "Freedom", he claims, "liberated inventors and other innovative thinkers and this gave us the steam engine and the Industrial Revolution". I am not in any way suggesting that this is wrong, and it is indeed one of the ways in which good citizenship arrangements as I discuss them in the book might have engendered innovation. But rather than highlighting the idea of freedom, I would submit that the same conditions gave rise to both the idea and the practices of urban citizenship in European towns: the elements of political autonomy embedded in town charters, as well as the competition between towns and states. In the second part of my book I argue that these were necessary, but not sufficient, conditions for creating prosperity from

6. See, for example, Derek Heater, Citizenship: The Civic Ideal in World History, Politics and Education (Manchester, 1990); Andreas Fahrmeir, Citizenship: The Rise and Fall of a Modern Concept (New Haven, CT, 2007).

7. R. Bin Wong, China Transformed: Historical Change and the Limits of European Experience (Ithaca, NY, I997), pp. I-8. 
citizenship. The additional condition was an effective collaboration between national and local institutions, including civic institutions, in the emerging states of pre-modern Europe. That effective collaboration was available in Italian cities of the Renaissance, in the Low Countries during the sixteenth and seventeenth centuries, and in England from the late seventeenth century. Freedom, or "liberty", could be part of this package. ${ }^{8}$

A related point seems to be raised in Lynch's review about religion. In the years before I published the book, I presented the outlines of my argument in numerous seminars. The most frequently asked question I got was "what about religion?". I took this as a question about religious doctrine and citizenship. My, admittedly Eurocentric, answer was always that I saw no distinction between Catholic and Protestant Europe for the topic of citizenship. Lynch, however, provides a different, and much more sensible angle, because she says that including religious organizations would have allowed me to add a strong dose of female agency to my story. I think she is right to say that this has been a "missed opportunity".

\section{CITIZENSHIP, LOCAL AND NATIONAL}

Citizens without Nations was written as a revisionist work. I wanted to challenge the predominant view that the political history of pre-modern societies is by definition a history of state institutions, their personnel, and their policies. My focus is deliberately on the local level because, as I argue in the book, this is where citizenship mattered most. Both Lynch and Wong raise questions about the role of the national in my narrative. They do so in two distinct ways. Lynch asks how the story I tell contributed to the formation of nationhood. Although it is generally assumed that "nationhood" is really a nineteenthcentury phenomenon, hence outside the temporal scope of my book, there were all sorts of earlier stirrings that I might have discussed. ${ }^{10}$ I plead guilty to this failing. I am not sure if it would have made a fundamental difference to the final result, and I am pretty sure it would have made the work even more complex. But I also admit that, in contrast to the omission of religion, this was not an aspect I considered in any detail. Nationhood went out the window, together with the "national" view of political history.

8. Eco Haitsma Mulier and Wieger Velema (eds), Vrijheid. Een geschiedenis van de vijftiende tot de twintigste eeuw (Amsterdam, 1995); Quentin Skinner, Liberty before Liberalism (Cambridge, 1998).

9. For a good example of what Lynch suggests, see Josine Blok, Citizenship in Classical Athens (Cambridge, 2017), ch. 5 .

I0. Eric J. Hobsbawm, Nations and Nationalism since 1780: Programme, Myth, Reality (Cambridge, 1990); Linda Colley, Britons: Forging the Nation, 1707-I837 (New Haven, CT, 1992). 
Wong's criticism is of a different kind. He argues that I should have made a more fundamental distinction between the states of Europe and the empires of Asia. For various reasons, the internal and external dynamics of states and empires were different and by implication the place of citizenship - if we can still use that word - was different within these two types of polity. I understand his point and accept its validity, but I am at the same time reluctant to embrace it. I think it is fair to say that in the past decades both European and Asian history has benefited enormously from the sort of comparisons I attempt in my book. If, however, everything is declared to be distinct, the point and indeed the intellectual foundations of any comparison seem to disappear.

\section{CITIZENSHIP AND ECONOMIC DEVELOPMENT}

In Citizens without Nations I took a bit of a gamble, which is already coming home to roost. The gamble was that I connected citizenship with economic performance. In this I was inspired by institutionalists like Douglass North, Avner Greif, Daron Acemoğlu and James Robinson, and Robert Putnam. ${ }^{\text {I }}$ They all argued that institutions had an impact on a society's economy. These authors focus on different types of institution, however. North and his co-authors are especially interested in the security of property rights. Greif's emphasis is on the security of trade, and more recently on the role of families. Acemoğlu and Robinson highlight the role of governments. Putnam, finally, sees civil society as the key element. My interest in citizens is inspired by a conviction that the quality of a society cannot be determined by its elites alone. In this respect, Putnam's work is closest to mine.

To make the point that citizenship could make a difference, I needed some sort of output measure, or benchmark, for a comparison between various local citizenship regimes. It would have been commensurate with the approach of the book to use local indicators, such as the growth of urban populations. I did not do that, for two reasons. Firstly, there is a serious endogeneity problem: was urban growth a result of good citizenship arrangements, or the other way around? Secondly, levels of urbanization are probably best measured regionally, because the growth of individual towns or cities - think of London - may be at the expense of nearby towns, without citizenship being the decisive factor. Therefore, I decided to follow De Vries's

II. Douglass C. North, Institutions, Institutional Change and Economic Performance (Cambridge, 1990); Avner Greif, Institutions and the Path to the Modern Economy: Lessons from Medieval Trade (Cambridge, 2006); Daron Acemoğlu and James Robinson, Why Nations Fail: The Origins of Power, Prosperity, and Poverty (London, 2012); Robert D. Putnam, Making Democracy Work: Civic Traditions in Modern Italy (Princeton, NJ, 1993); idem, Bowling Alone: The Collapse and Revival of American Community (New York, 2000). 
example $\mathrm{I}^{\mathrm{I} 2}$ and use national output measurements. Having collaborated closely during the past twenty-five years with Jan Luiten van Zanden (to whom the book is also dedicated), I was, moreover, impressed by the progress that economic historians have made in recent years in reconstructing historical series of GDP per capita figures. At the same time, I am well aware of the fragility of this exercise, especially for centuries that are further removed from the reasonably reliable data we have for the nineteenth and twentieth centuries.

In my book I argue that, in Europe, there seems to be a relationship between strong economic performance, first in Renaissance Italy, subsequently in the Low Countries, and finally in England after the Glorious Revolution, in regions where towns had a major impact on national government. This created simultaneously a constraint on the state and an impetus for the state to pursue policies that would support urban prosperity. I also argue that this was not the normal situation in pre-modern Europe, for a variety of reasons. I then go on to say that this argument might be extended to the two Asian states that I have studied, the Chinese and Ottoman empires, where I found a lot of local citizenship practices but levels of economic prosperity that were well below those of Europe's most advanced regions, and more like those of the "average" European countries, which similarly had lots of local citizenship but no mechanism to influence state policies.

For all this I relied on the latest research published in the 2015 study by Broadberry et al. of British economic growth. ${ }^{13}$ As it happens, just months after the publication of Citizens without Nations, Broadberry, together with Guan and Li, published new figures for China that do not revise the earlier series for China as a whole very substantially, but add specifications for the Lower Yangzi region that broadly confirm Pomeranz's claim that it was developed to more or less the same degree as the most advanced regions of Europe. ${ }^{\mathrm{I}}$ Jack Goldstone is very right to ask what this implies for my argument.

I am not in a position to comment on the validity of the further revisions that Goldstone is adding to Broadberry, Guan, and Li. However, it seems to me that his comments can be taken up in three distinct ways. The first, obviously his point, is that he is right and I am wrong and therefore my thesis about the connection between local citizenship and economic performance is disproved. I am not sure, however, why this then implies that "intellectual and religious freedom" is the correct answer, as Goldstone claims. A second response might be to see if these figures will bear the scrutiny of other scholars.

I 2. De Vries, European Urbanization.

I3. Stephen Broadberry, Bruce Campbell, Alexander Klein, Mark Overton, and Bas van Leeuwen, British Economic Growth, I270-1870 (Cambridge, 201 5), pp. 375-376, Table 10.02.

I4. Stephen Broadberry, Hanhui Guan, and David Daokui Li, "China, Europe, and the Great Divergence: A Study in Historical National Accounting, 980-1850", Journal of Economic History, 78:4 (2018), pp. 955-1000. 
Numbers about China have been subject to contradictory claims and substantial revisions in recent years. ${ }^{\text {Is }}$ A lot is riding on the weights assigned to the Yangzi delta's economic performance vis-à-vis the whole of China, for which Broadberry, Guan, and Li themselves offer two very different scenarios, one supporting Goldstone's interpretation and the other mine. ${ }^{16} \mathrm{~A}$ third response is suggested by Wong's contribution, who says that the political and governance environment in China was so radically different from the situation prevailing in Europe that trying to fit them both into the same analytical mould was a bad idea from the very start.

Whether I am right or wrong is, in the long run, less important than the benefits that history and contemporary society might reap from more research along the lines suggested by my critics and myself. A recent issue of Citizenship Studies offers fascinating explorations of the history of Asian citizenship, partly along the lines suggested here. ${ }^{17} \mathrm{I}$ am hoping for more intelligent criticisms.

I 5. For example, in Yi Xu, Bas van Leeuwen, and Jan Luiten van Zanden, "Urbanization in China, ca. I 100-1900", Frontiers of Economics in China, I 3:3 (2018), pp. 322-368.

16. Broadberry, Guan, and Li, "China, Europe, and the Great Divergence", figures 8 and 9.

17. Paul Bijl and Gerry van Klinken (eds), "Citizenship in Asian History", special issue of

Citizenship Studies, 23:3 (2019), pp. I 89-294. 